\title{
Giza 3D: Digital archaeology and scholarly access to the Giza Pyramids: The Giza Project at Harvard University
}

\section{Citation}

Der Manuelian, Peter. 2013. "Giza 3D: Digital Archaeology and Scholarly Access to the Giza Pyramids: The Giza Project at Harvard University." In Proceedings of DigitalHeritage 2013 (Digital Heritage International Congress), Marseille, France, October 28 - November 1, 2013, vol. 2: 727-734. Institute of Electrical and Electronics Engineers.

\section{Published Version}

doi:10.1109/DigitalHeritage.2013.6744842

\section{Permanent link}

http://nrs.harvard.edu/urn-3:HUL.InstRepos:12560998

\section{Terms of Use}

This article was downloaded from Harvard University's DASH repository, and is made available under the terms and conditions applicable to Open Access Policy Articles, as set forth at http:// nrs.harvard.edu/urn-3:HUL.InstRepos:dash.current.terms-of-use\#OAP

\section{Share Your Story}

The Harvard community has made this article openly available.

Please share how this access benefits you. Submit a story.

\section{Accessibility}




\title{
Giza 3D: Digital Archaeology and Scholarly Access to the Giza Pyramids
}

\author{
The Giza Project at Harvard University
}

\author{
Peter Der Manuelian \\ Dept. of Near Eastern Languages \& Civilizations; Dept. of Anthropology; Harvard Semitic Museum \\ Harvard University \\ Cambridge, MA, USA \\ peter_manuelian@harvard.edu
}

\begin{abstract}
For the famous Giza Pyramids, the Sphinx, and surrounding tombs and temples, just west of modern Cairo (3rd millennium BCE), the Giza Project at Harvard University is blending older traditional archives (dig photos, archaeological drawings, object metadata) with realistic $3 D$ visualization of the site. This marriage of old and new provides revolutionary access to Giza, its statues, hieroglyphic inscriptions, architecture, and wall decoration. Real-time immersive models allow us to pose new research questions, provide interactive classroom instruction, and investigate diachronic approaches to Giza's evolution over several millennia.
\end{abstract}

Giza, Egyptology, archaeology, pyramids, mastabas, Harvard University, Museum of Fine Arts, Boston, George Reisner, digital archaeology, Dassault Systèmes, 3D immersive models, educational technology

\section{INTRODUCTION AND SIGNIFICANCE}

There are few archeological sites that produce instant worldwide recognition as successfully as the Giza Pyramids, just west of modern Cairo (fig. 1). Not only is the Great Pyramid of Khufu (Dynasty 4, 2551-2528 BCE) the only surviving Wonder of the Ancient World, but the site hosts the famous Sphinx, several additional royal pyramids, mortuary temples, settlements, and thousands of burials of the governing elite during ancient Egypt's Old Kingdom. Both the royal pyramid complexes, and the surrounding rock-cut and built limestone "mastaba" tombs of the elites were intended to serve as "mansions of eternity" for their owners, guaranteeing a successful afterlife with all the burial equipment needed to achieve that goal. Recent excavations have revealed not only additional tombs and associated grave goods, but the settlements of some of the workers and administrators conscripted to build the Pyramids as well.

From a modern archaeological standpoint, it is critical to bear in mind that such cemeteries as the Giza Necropolis functioned not as empty, quiet, abandoned burial places, but as thriving administrative centers that played important roles in the lives of the Egyptians, not just in their deaths. This fact, combined with the Egyptian propensity to adorn their funerary monuments with identifying inscriptions and scenes, either in paint or in carved relief (or both), converts the Necropolis into a primary source for the study of almost any aspect of ancient Egyptian civilization. Biographical texts describe the careers of selected officials. Scenes of craftsmanship, livestock, religious ritual, agriculture, boating, and the ubiquitous presentation of offerings, all present glimpses into the daily lives of Egyptians of all societal levels. Artistic styles and evolution are represented in the two-dimensional wall decorations as well as in sculptures in the round placed in the tombs and temples. And, of course, the study of mortuary architecture is available in the stone, wood, and mud-brick structures themselves. In short, the significance of major cemetery sites such as Giza cannot be overstated for all types of Egyptological inquiry. And while the Pyramids and surrounding tombs date primarily to the Old Kingdom, Giza saw a renaissance at several stages of later Egyptian history, particularly the New Kingdom (1550-1070 BCE) and the Late Period (743-343 BCE). The Sphinx itself presents a diachronic study in decoration, alteration, and extension.

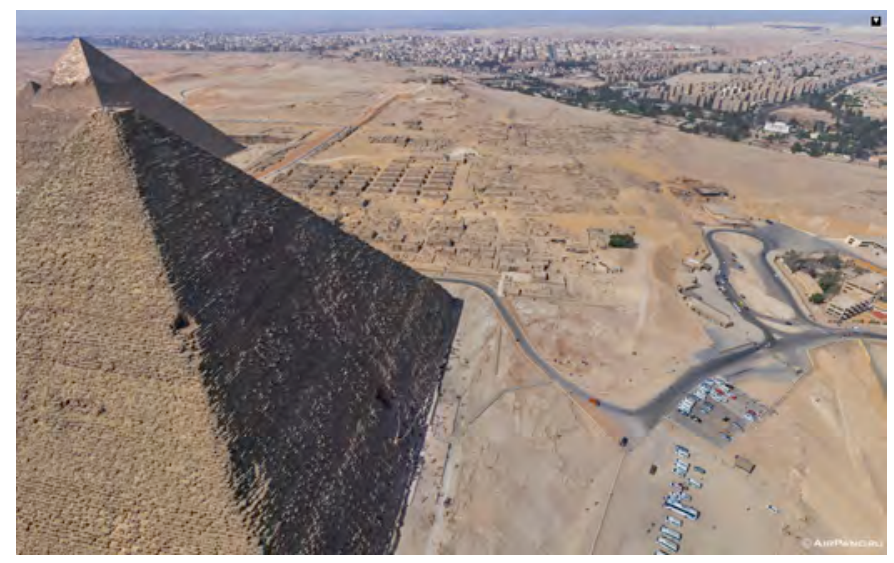

Fig. 1. Aerial view of the three Giza Pyramids at left (from near to far: Khufu, Khafre, and Menkaure, barely visible), looking west towards the many "mastaba" tombs of the Western Cemetery. Photo courtesy of AirPano.com. 


\section{BRIEF HISTORY OF EXPLORATION AT GIZA}

\section{A. Early Explorers}

What began as a hunt for treasure eventually evolved at Giza into modern, responsible archaeology. The first organized explorations of the Giza Necropolis occurred during the beginning of the nineteenth century. Before then, the relationships of the royal to the "private" (i.e. non-royal) elements of the site, from tomb to temple, and temple to pyramid, were not well understood. After the so-called Battle of the Pyramids in 1798, Napoleon's savants began laying the foundations of a western approach (for better or for worse ${ }^{1}$ ) to the study of the Egyptian past. Most prominent among the French expedition's many discoveries was, of course, the Rosetta Stone, key to the ancient Egyptian language. But J.-F. Champollion did not decipher Egyptian hieroglyphs until an additional twenty-three years later, in $1822 .^{2}$

Among some of the explorers to work at Giza, Genoese sea captain Giovanni Caviglia (1770-1845) examined the Great Pyramid in 1817, and later cleared the Sphinx. The contributions by W.H. Vyse and J.S. Perring in 1837 to our understanding of the royal monuments at Giza are also substantial, but their invasive methods were at times horrifying. Vyse and Perring eventually explored all three royal pyramids, all of Menkaure's subsidiary queens' pyramids, the Sphinx, and several other locations.

The next significant Giza campaign was the Prussian expedition in the early 1840s led by Karl Richard Lepsius. His team identified and numbered many Giza tombs, and documented scenes and inscriptions that today are damaged, or have disappeared completely. The results appeared in the oversized folio series Denkmaeler aus Aegypten und Aethiopien (Berlin, 1849-1856).

In 1858, the Egyptian Viceroy Said Pasha created the Service des Antiquités, with French Egyptologist Auguste Mariette as its first director. At Giza, Mariette cleared the Sphinx completely, and discovered the Khafre Valley Temple, immediately to the south. ${ }^{4}$ Serious exploration of Giza towards the end of the nineteenth century and early twentieth then stopped, with the exception of work by the English archaeologist Flinders Petrie, and later by the American George A. Reisner. Petrie spent his first of two seasons (1880

[1] For earlier, non-western, approaches to ancient Egypt, see O. el Daly, Egyptology: The Missing Millennium. Ancient Egypt in Medieval Arabic Writings. London: University College London, 2008.

[2] See N. Burleigh, Mirage. Napoleon's Scientists and the Unveiling of Egypt. New York: Harper, 2007; P. Strathern, Napoleon in Egypt. New York: Bantam Books, 2007.

[3] R.W.H. Vyse, Operations carried on at the Pyramids of Gizeh in 1837, London: J. Fraser, 1840-42; R.W.H. Vyse and J.S. Perring, The Pyramids of Gizeh from actual survey and measurement London: J

[2] See N. Burleigh, Mirage. Napoleon's Scientists and the Unveiling of Egypt. New York: Harper, 2007; P. Strathern, Napoleon in Egypt. New York: Bantam Books, 2007.

[3] R.W.H. Vyse, Operations carried on at the Pyramids of Gizeh in 1837 , London: J. Fraser, 1840-42; R.W.H. Vyse and J.S. Perring, The Pyramids of Gizeh, from actual survey and measurement. London: J. Fraser, 1839-42.

[4] A. Mariette, Les mastabas de l'ancien empire. Paris: F. Vieweg, 1889; E. David, Mariette Pacha, 1821-1881. Paris: Pygmalion/G. Watelet, 1994. and 1882) creating triangulations for the Pyramids, since the bases were still buried and could not be accurately measured. Later, when the Service des Antiquités finally decided to apportion the Giza Plateau for excavation, several concessionaires applied for the site: George Reisner (Hearst Expedition, Berkeley), Georg Steindorff (Leipzig), and Ernesto Schiaparelli (Turin). The three scholars amicably apportioned the Pyramids and surrounding cemeteries amongst themselves. In 1904, Reisner's patron, Phoebe Apperson Hearst (18421919), informed him that she could not continue to support his work. Thus, the Hearst Expedition became the Harvard University-Boston Museum of Fine Arts Expedition, beginning with the 1905-1906 field season. Reisner proved to be one of the leading archaeologists of his generation, and it is to him that we owe the massive excavation archive that survives today, and on which so much of our work is based. Reisner died at the Pyramids in 1942. Steindorff worked in the central strip of the Western Cemetery in 1903. The Italian mission did not work systematically, and soon turned its Giza concession over to Reisner and the (now) HU-MFA Expedition in $1905 .^{5}$

In 1911, Steindorff (Giza) and fellow German Egyptologist Hermann Junker (Aniba, Nubia) exchanged concessions and switched excavations. In all, Junker worked for seven seasons at Giza, covering 1912-14, and 1925-29, with a forced interruption during World War I. Junker later published the results of his work in both the Western Cemetery, and the cemetery immediately south of the Great Pyramid. ${ }^{6}$

The discoveries made by these expeditions are far too numerous to describe here in any great detail. But a few highlights include the so-called slab stelae, the "reserve heads," the mysterious burial chamber of Queen Hetepheres, and spectacular royal sculptures from the Menkaure pyramid complex, along with systematic analyses of mortuary architecture and settlement archaeology. Junker's excavations produced the tomb of Great Pyramid engineer Hemiunu (G 4000). He also found the Fifth Dynasty mastaba family complex of Kaninisut, whose chapel is now in Vienna.

When Selim Hassan, who trained with Junker in 1928, took over the Central Field concession, east of the Khafre Pyramid, it marked the first large-scale expedition by native Egyptian archaeologists at the site. Hassan's project continued for ten

[5] G.A. Reisner, A History of the Giza Necropolis I. Cambridge, MA: Harvard University Press, 1942; S. Curto, Gli Scavi Italiani a el-Ghiza (1903). Rome: Centro per le Antichita e la Storia dell-Arte del Vicino Oriente, 1963; M Lehner, The Complete Pyramids. London: Thames \& Hudson, 1997; J.-P. Corteggiani, The Great Pyramids. London and New York: Thames \& Hudson, 2006.

[6] H. Junker, Gîza vols. 1-12. Vienna and Leipzig: Hölder-PichlerTempsky, and Rudolf M. Rohrer, 1929-1955. Downloads available: http://www.gizapyramids.org/code/emuseum.asp?newpage=authors_list.

[7] P.D. Manuelian, "Die Erforschung der Nekropole Giza von 1800 bis heute," in Im Schatten der Pyramiden. Die österreichischen Grabungen in Giza (1912-1929). Exhibition catalogue. Vienna: Kunsthistorisches Museum, 2013, pp. 12-39; R. Hölzl, Die Kultkammer des Ka-ni-nisut im Kunsthistorischen Museum Wien. Vienna: Brandstätter, 2005. 
years, and came to include the Pyramid Temple east of the Great Pyramid of Khufu. ${ }^{8}$

\section{B. The Modern Era 1950-2000}

In the 1950s, Abdel Moneim Abu-Bakr commenced work on the northwest corner of the former American concession, in the far Western Cemetery. ${ }^{9}$ Soon after (in 1954), Egyptian Antiquities Organization architect Kamal el-Mallakh (19181987) found two long boat pits on the south side of the Great Pyramid. ${ }^{10}$ These were covered with massive limestone slabs; the eastern pit revealed a dismantled boat - in 1,224 individual pieces - made of Lebanese cedar. At this writing the second boat is being prepared for excavation and reconstruction.

In 1971, Museum of Fine Arts, Boston, curator W.K. Simpson created the "Giza Mastabas" Series, to publish part of Reisner's Harvard-MFA Expedition backlog. To date, eight volumes have appeared in print. ${ }^{11}$ Meanwhile, former Giza inspector Zahi Hawass and American archaeologist Mark Lehner explored the Sphinx, starting in 1978. Lehner's project has now established the first control network over the entire Giza Plateau, while Hawass initiated his "site management plan" in 1987, the first modern attempt to conserve Giza in toto, with a strategy to balance the competing needs of access, tourism, scholarship and preservation.

In 1988, Lehner moved his excavations to the zone south of the so-called "Wall of the Crow," 400 meters south of the Sphinx. His interdisciplinary approach to the "lost city of the pyramids" has revealed invaluable data on the pyramid builders' ancient settlements, housing, diet, social organization, administration, and architecture. This zone represents the largest exposed area of Old Kingdom settlement anywhere in Egypt, and it has provided the greatest assemblage yet of human and animal bones, seal impressions, ceramics, plant remains and other finds. ${ }^{12}$

\section{III. “Transforming THE MEdium": The GIZA ProjeCt}

The cursory survey of exploration of the Giza Necropolis above, which has omitted scores of additional projects, hints at not only the daunting nature of the archaeological matrix on the Giza Plateau, but also the difficulty of keeping abreast of wideranging scholarly research. The ever-accumulating volume of data has become unwieldy, and no single scholar can command

[8] S. Hassan, Excavations at Gîza vols.1-10. Oxford: Oxford University Press, Government Press, and Cairo: Government Press, Bulâq, 19321960. Downloads available:

http://www.gizapyramids.org/code/emuseum.asp?newpage=authors_list.

[9] A.M. Abu-Bakr, Abdel Moneim, Excavations at Giza 1949-1950. Cairo: Government Press. 1953. This area was further explored in the 1990s and early 2000s by an expedition from Cairo University and Brown University, under the direction of T. Handoussa and E. Brovarski.

[10] M.Z. Nour, Z. Iskander, M.S. Osman, and A.Y. Moustafa, The Cheops Boats, Part I. Cairo: General Organization for Govt. Printing Offices, 1960; Z. Hawass, "The Royal Boats at Giza," in The Treasures of the Pyramids, Z. Hawass, Ed. Vercelli: White Star, 2003, pp. 164-71.

[11] At this writing these volumes are available for download at http://www.gizapyramids.org/code/emuseum.asp?newpage=gizamastaba s.

[12] For Lehner's work and publications, on behalf of Ancient Egypt Research Associates, see http://www.aeraweb.org. expertise in the many disciplines required for contemporary archaeological research at the site. One potential solution to the problem is the application of new technology to collecting and parsing Giza data. To that end, the Giza Archives Project in Boston, USA was established in the year 2000. Funded for ten years (2000-2011) at the Museum of Fine Arts, Boston, by generous grants from the Andrew W. Mellon Foundation in New York, the Project began with the largest single collection of Giza archaeological data, the archives of the Harvard University-Boston Museum of Fine Arts Expedition. ${ }^{13}$

It became clear that no comprehensive approach to the Giza Necropolis would be possible without an integrated foundation of older archaeological data, cross-referenced and readily available to all. Only upon this foundation could more modern techniques, such as 3D visualization, be applied (see below). Thus the Giza Archives Project began by converting 21,000 glass plate excavation negatives (in three different sizes), 3,000 pages of excavation diaries, and the metadata for 20,000 finds, recorded in forty Object Register ledger books (the original excavation "database") to electronic form. The intellectual challenge lay in discerning how to parse and organize these data. Individual Egyptian "mastabas" (non-royal tombs) became the unifying central nodes of a modular SQL database organizational structure. Thus for any give tomb (or temple, pyramid, or other monument), the appropriate archaeological materials were linked. At this point additional data were added, such as line drawings of wall scenes, architectural plans and sections, scholarly publications as well as unpublished manuscripts, modern (color) photography, QTVR (Quicktime Virtual Reality) panoramas, and information on ancient and modern individuals connected to the site-tomb owners and others named in hieroglyphs on tomb walls, modern excavators, photographers, etc. Searches could travel in any one of a number of directions. For example, the search for a specific tomb returns all photos, object data, diary pages, plans, drawings, manuscripts etc. that illustrate, mention, or derive from that particular tomb. Conversely, searching on a specific photograph links back to the records for the tomb(s) or object(s) illustrated in the picture. Artifactual data are, of course, likewise linked to findspots and tomb provenience. Bibliography items are embedded in the database, as are thesaurus terms that allow users to search images by content. It is thus possible to search and locate all images of musicians, or of seated females, or fishing scenes.

The system described above has proven to function efficiently, but it lays undue emphasis on modern excavations and expeditions, rather than on a holistic approach to the archaeological site itself. For comprehensive research, the data would appear skewed if all information were available for tomb G 4140 (Meretites), a HU-MFA Expedition-excavated tomb, but no information were available for the tomb immediately adjacent to it, G 4150 (Iunu), because it happened to be excavated by the German-Austrian Expedition. For this reason the attempt was made to collect and include Giza data from all major excavations that work(ed) at the site. Since 2006, all the principal "Giza institutions" from the early $20^{\text {th }}$

[13] P.D. Manuelian, "Eight Years at the Giza Archives Project: Past Experiences and Future Plans for the Giza Digital Archive," Egyptian \& Egyptological Documents, Archives, Libraries vol. 1, pp. 139-148, 2009. 
century expeditions have joined the Project, which currently continues its operations at Harvard University. The partner institutions include museums, universities and institutes in Berkeley, Berlin, Cairo, Hildesheim, Leipzig, Philadelphia, Turin, and Vienna. Needless to say, current, and even future, work at Giza is very much on our list for inclusion, as the Project strives to become the central repository for accessing all archaeological information about the site. At this writing, the Giza archives may be accessed at http://www.gizapyramids.org. We also see this type of database and website as the appropriate location for housing significant personal photographic collections, historic, vintage, stereo, aerial, and satellite views of Giza, and eventually even travelers' accounts over the course of several millennia of visiting the site. Mapping the rates of change, from climate change (humidity, migrating course of the ancient Nile, changing water tables) to modern alterations (excavators' debris, construction projects for tourism such as roads, stages, and parking zones, and restoration work) proves that Giza is a site in constant flux.

\section{3D VISUALIZATION}

With the archaeological imagery and documentation largely converted to electronic form, the Giza Project at Harvard has begun to develop the next generation of scholarly and popular access to the Giza Necropolis: 3D visualization. Some archaeological projects post their historical archives online; others create computer models and reconstructions of their ancient monuments. Our Project stands in the enviable position, thanks to decades of meticulous scholarship by American, German-Austrian, and Egyptian excavations, of basing $3 \mathrm{D}$ computer renderings on a rich archival body of data. In fact, our long-term goal is to blend the two: traditional archival documentation and immersive $3 \mathrm{D}$ environments, to "publish" Giza in ways that were heretofore impossible.

In this new 3D undertaking we have been fortunate to work with technology partners from Dassault Systèmes, ${ }^{14}$ whose real-time immersive environment is the software engine for the virtual Giza world that we currently use for teaching and for research. Collaborating between offices on three continents, our workflow consists of first analyzing the available data from the early $20^{\text {th }}$ century excavations. From these plans, notes, and images, supplemented by modern photography from recent years, and "ground-truthing" confirmations out at the site of Giza itself, we then create the 3D models of the individual monuments and load them into our overall Giza Plateau model (fig. 2). To avoid distractions and inaccuracies, we have worked to understand the appearance of the Plateau as it may have appeared some 4,500 years ago. This means removing elements of the modern landscape, such as excavators' debris dumps, and rerouting the Nile much closer to the site. ${ }^{15}$ Moreover, we have georeferenced all of the maps and plans where possible, since the original excavators of the first half of the twentieth century had no access to such precise mapping

[14] Dassault Systèmes website: http://www.3ds.com.

[15] K. Lutley and J. Bunbury, "The Nile on the Move," Egyptian Archaeology 32, pp. 3-5, 2008; http://ees.ac.uk/userfiles/file/EA32pp03-05-Lutley.pdf (accessed July 2013). technologies, and their plans are "free-floating" in space (fig. 3).

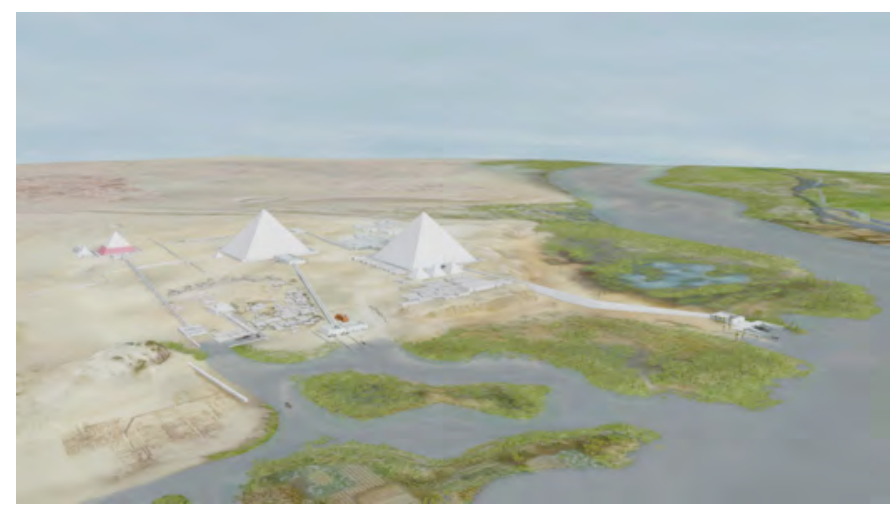

Fig. 2. 3D model of the Giza Plateau looking northwest.

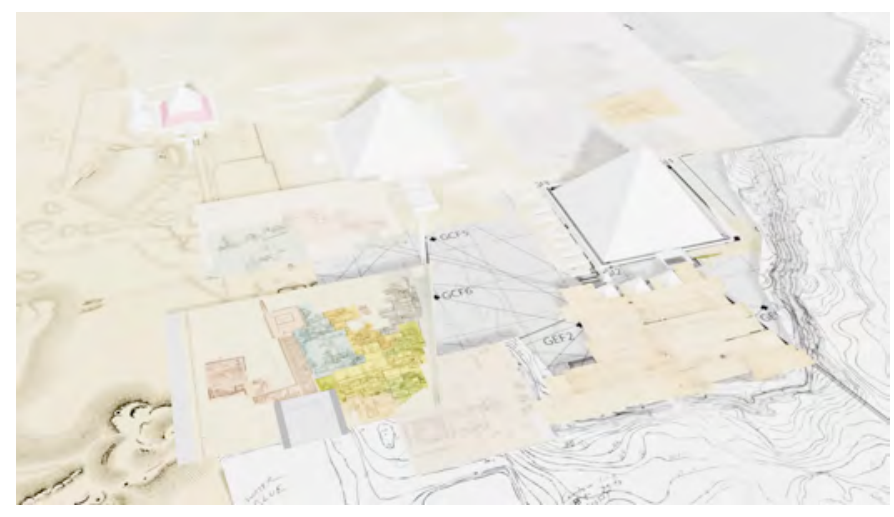

Fig. 3. Giza 3D model, with superimposed archaeological plans and topographical maps from various excavations and eras.

To date, only a small portion of the thousands of burial structures at Giza have been built in painstaking archaeological detail. And there are even more ancient objects to "return" virtually to their original findspots. But the major monuments are in place, and many of the mastaba tomb "shells" act as placeholders, presenting an accurate overview of the site as it might have appeared during the Old Kingdom. Exploring the model is a real-time exercise, where the user can "fly" over the monuments, traverse the site at ground level, or even descend down burial shafts to view the subterranean burial chambers and sarcophagi (fig. 4). As we continue to blend the old and the new, that is, the traditional excavation data with this new 3D research and teaching interface, users will be able to click on tomb or temple wall scenes or inscriptions, or on buried statues or other grave goods and instantly view in-situ discovery photographs, references to academic literature, dig diary descriptions, drawings, and other documentation. Moreover, different phases of the same monument are also available. For example, the courtyard of Menkaure's Valley Temple was occupied later in the Old Kingdom, creating a complex stratigraphic assemblage of mortuary temple architecture and settlement archaeology. Our 3D model allows the user to switch back and forth between these different eras to see the courtyard now empty, now filled with grain silos and other mud-brick structures (fig. 5). 

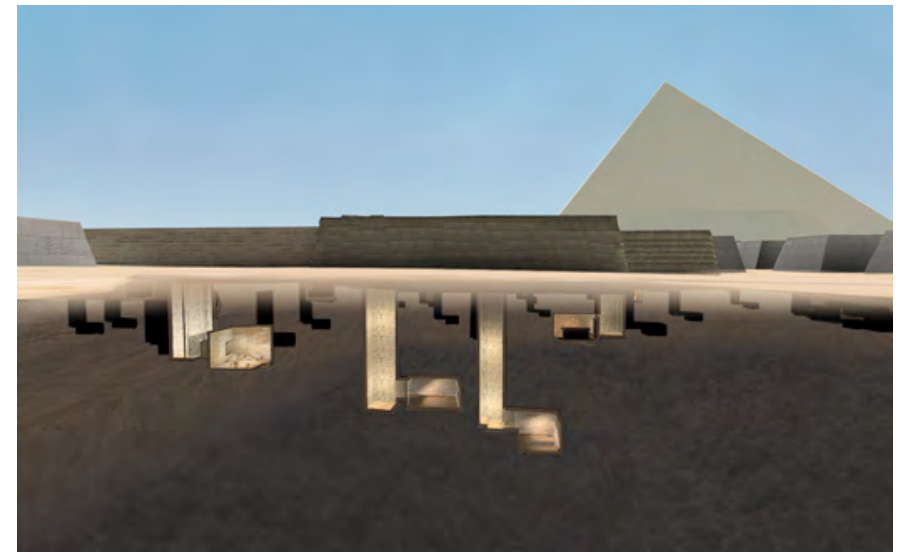

Fig. 4. 3D rendering of Giza superstructures (mastaba tombs) and substructures (shafts leading to burial chambers), looking east (G 2100 family tomb complex).

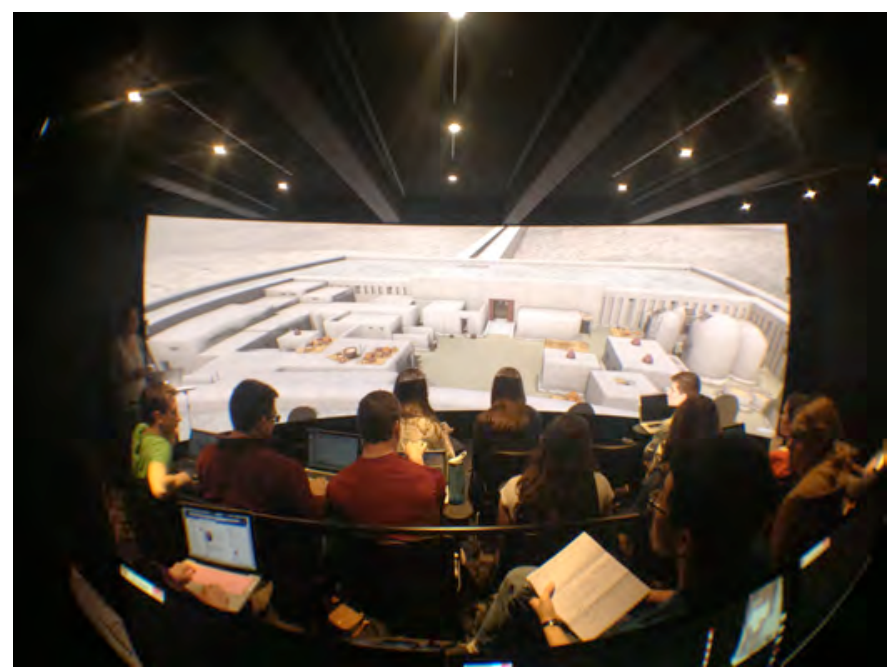

Fig. 5. The Menkaure Valley Temple courtyard, with late Old Kingdom settlement occupation, looking west; interactive 3D model in classroom setting in Harvard University's Visualization Center, 2013.

We have found that this 3D immersive environment is at its most powerful in large-scale visualization centers, such as exist at Harvard University (fig. 5). Here the students don 3D glasses, and the sheer scale of the site of Giza becomes more comprehensible on the 23 -foot parabolic screen. ${ }^{16}$ Since the

[16] The Harvard Visualization Center is a research institute, industry-grade facility, sized for groups and small class session instructional use. It includes the following technical components as of July 2013: $23 \times 8 \mathrm{ft}$ cylindrical screen (120 degrees of arc); two edge-blended, highresolution active stereo digital Barco Galaxy NW-7 MKII projectors with High Brightness SLM Lenes TLD+ (1.2:1); XDS-200 wall controller with XDS CC v3 XDS-Software supporting up to 6 independent stereo sources; primary image source-Linux, 4 dual-core Opteron cpu, 128GB RAM, Nvidia Quadroplex D2; secondary image source-ScalableGraphics Windows DTC cluster, 3 Dell Precison workstation, dual cpu, 48 GB RAM, Nvidia FX Pro 5800 \& Pro 6000 GPUs; tertiary image source -Windows 7 Professional, Dell Precision R5500 rack-mount workstation Intel(r) Xeon(r) Quad Core 12GB5 DDR3 RDIMM, NVIDIA(r) Quadro(r) 6000; additional image sourceMac OS 10.5 podium laptop; Stereo Graphics/Real CrystalEyes Stereo Viewing eyewear. model is navigable in real-time, questions and discussion points can develop organically during class time, for the entire site of Giza is accessible, an advantage that a preset linear video cannot offer. However, since most of the world lacks access to such powerful presentation tools, the 3D models may also be viewed over the Internet on conventional computer screens, even in 3D with inexpensive (US \$00.30) anaglyph 3D glasses. At this writing the website is located at http://www.3ds.com/giza3d.
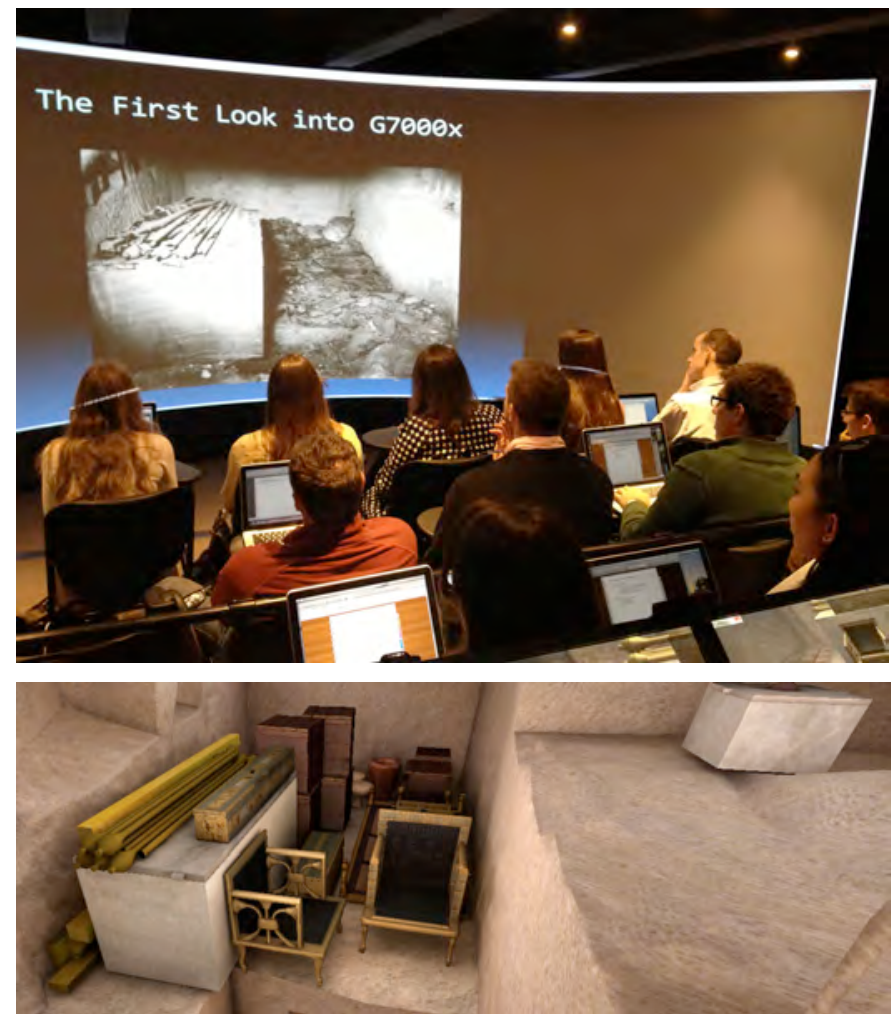

Fig. 6. Above: excavation photo showing the 1925 state of the burial deposit of Queen Hetepheres (G 7000 X), looking south. Below: reconstructed 3D model view of the chamber.

In addition to providing a formidable teaching tool, the 3D Giza Plateau model sets the stage for innovative research questions, and provides viewpoints not normally attainable by humans. For example, users may descend almost one hundred feet $(30.5 \mathrm{~m})$ into the unfinished burial equipment chamber of Queen Hetepheres (G 7000 X), discovered on the eastern side of the Great Pyramid in 1925. While the royal furniture had badly deteriorated over 4,500 years, the Giza Project 3D models can recreate the original appearance of the chamber in the Fourth Dynasty, based on the HU-MFA Expedition's copious notes, photographs and drawings (fig. 6). One of the queen's chairs was never reconstructed, but this reconstruction has now taken place in the $3 \mathrm{D}$ environment, allowing for detailed study that was previously impossible. Many more questions remain surrounding this tomb, chief of which is an explanation for the absence of a body inside the alabaster sarcophagus. 3D visualization may help us piece together the chronological deposition sequence of burial equipment placed in the tomb, which in turn ties in with Pharaoh Khufu's 
construction work on the surface above. We may yet be able to explain the Hetepheres mystery with this new approach. ${ }^{17}$

In another example, a burial chamber west of the Great Pyramid has been restored to its 1906 (plundered) condition. Fragments of a wooden coffin, and scattered human remains filled the chamber. Visualization of this deposit has helped us associate this unnamed burial with the adjacent tomb of a man named Merib (G 2100-I), which is inscribed and even contains a wall representation of his mother. The bones in our chamber most likely belong to this woman, named Sedit, who would thus be the eldest tomb-owner of a three-tomb family complex. $^{18}$

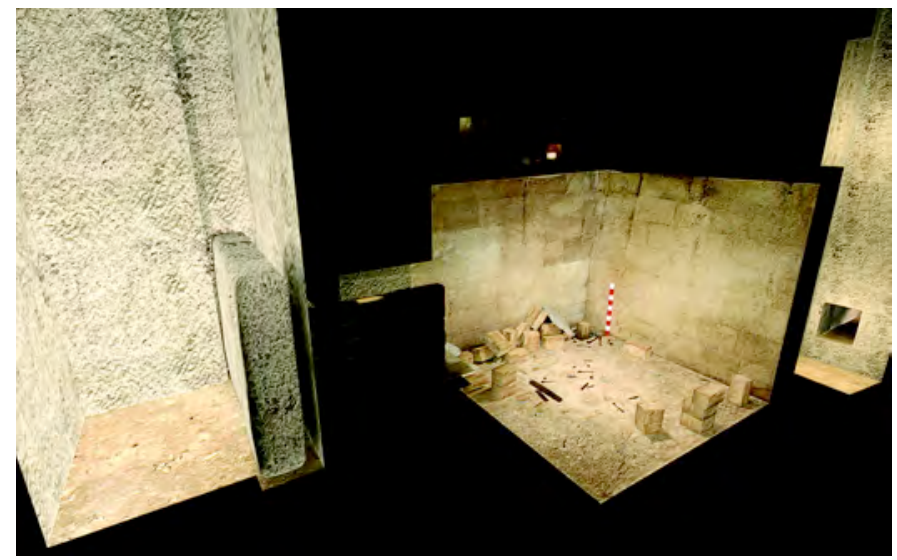

Fig. 7. 3D model of tomb G 2100, shaft A and subterranean burial chamber of Sedit, looking southeast.

In a decorated chapel, belonging to a Queen Meresankh III (G 7530-sub), east of the Great Pyramid, the reconstruction of sunlight passing through a window (still extant today) illustrates some of the architectural and orientation decisions on the part of the Egyptians, for the beam of cast light seems to be aimed at a significant location on the opposite wall. This otherwise insignificant feature ties in to the chronological development of this entire part of the cemetery, for adjacent tombs may or may not have blocked this light, indicating their pre- or post-dating of the tomb in question (figs. 8-9).

[17] See H.-H. Münch, "Categorizing Archaeological Finds: the Funerary Material of Queen Hetepheres I at Giza," Antiquity 74, pp. 898-908, 2000; M. Lehner, The Pyramid Tomb of Hetep-heres and the Satellite Pyramid of Khufu, Sonderschriften Mitteilungen des Deutschen Archäologischen Instituts Abteilung Kairo 19. Mainz: Philipp von Zabern, 1985; G.A. Reisner and W.S. Smith, A History of the Giza Necropolis. vol. 2, The Tomb of Hetep-Heres the Mother of Cheops: A Study of Egyptian Civilization in the Old Kingdom. Cambridge, Mass.: Harvard University Press, 1955.

[18] P.D. Manuelian, Mastabas of Nucleus Cemetery 2100. Part 1: Major Mastabas G 2100-2220. Giza Mastabas Series volume 8. Boston: Museum of Fine Arts, 2009, pp. 48-67.

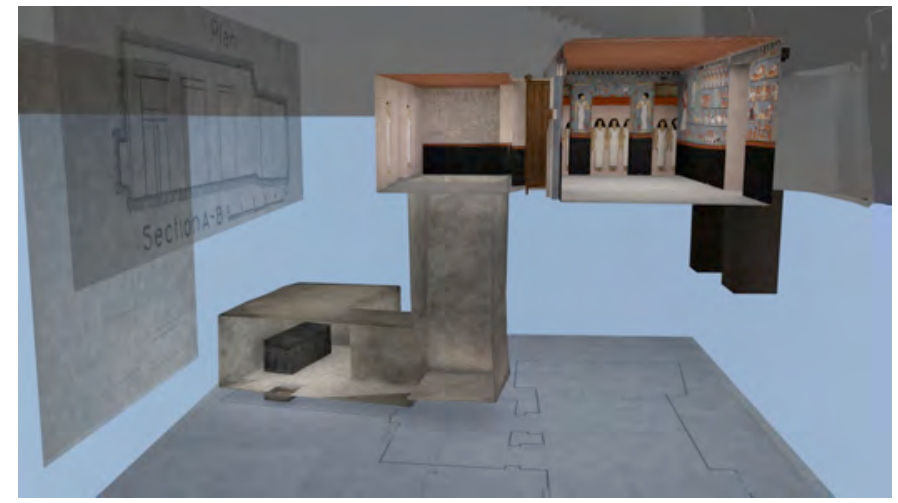

Fig. 8. Subterranean chapel complex of Queen Meresankh III (G 7530-sub), showing original exavators' plan and section drawings from 1927 superimposed over the the 3D model; looking north.

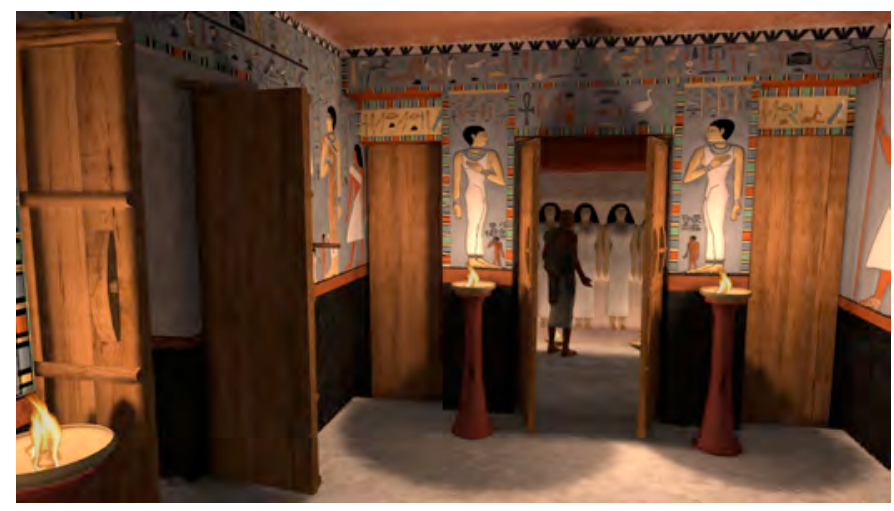

Fig. 9. 3D model of subterranean chapel of Queen Meresankh III (G 7530sub), reconstructed view, looking north.

Reconstructing the royal temples associated with the pharaonic pyramid complexes has allowed us to revisit current scholarly debates about the size of royal statuary that once adorned the temple courtyards, but which today survive only in fragments. None of these issues is highlighted with such clarity as when they appear in the 3D model, surrounded by their appropriately reconstructed contexts (fig. 10).

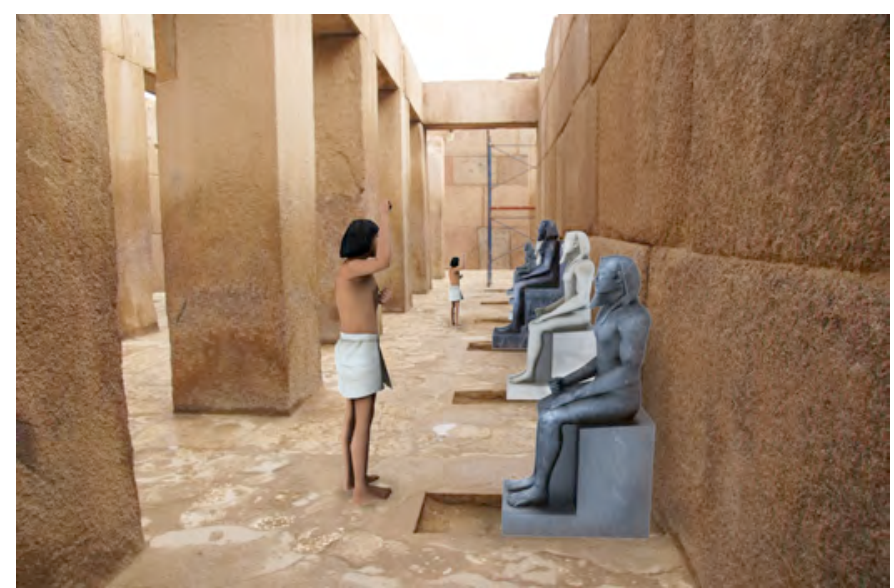

Fig. 10. Khafre Valley Temple photo, with 3D model reconstructions of royal statuary (and animated human characters for scale) placed in the floor sockets as an experiment to aid in hypothesizing their original sizes, looking west. 
Finally, we might note one other advantage provided by our 3D visualizations: the addition of animated characters. Animated ancient Egyptians and even selected animals may be added to the models to provide a sense of scale and purpose to the structures. Our experience shows that students routinely cite the animated humans as particularly useful for interpreting the functions of specific buildings. On the research level, these characters allow us to theorize and construct scenarios, such as the locations of specific funerary rituals, or the number and nature of the participants involved: priests, royal family members, mourners, etc. (fig. 11). The addition of actual avatars, representations of users in the virtual world, may eventually enhance the interactive experience further.

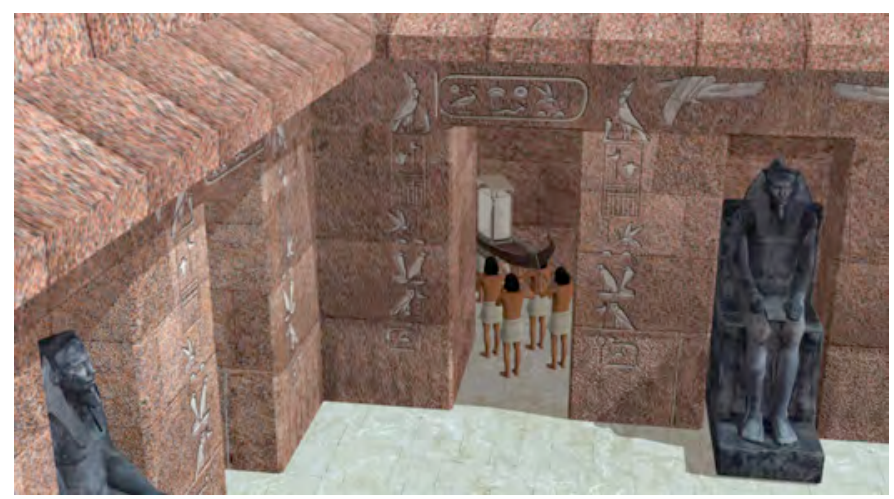

Fig. 11.3D model of the Khafre Pyramid Temple, with animated human characters carrying a sacred barque past colossal statues; looking west.

\section{Challenges}

While the $3 \mathrm{D}$ visualizations described above can provide extremely powerful research and teaching tools, they also present several challenges, foremost of which is that of academic accuracy, and our ability to distinguish archaeological certainty from conjecture. ${ }^{19}$ Best practices for flagging these distinctions are open to discussion. Some would shy away from realistic renderings, preferring wireframe or gray basic shape models in order not to mislead the user. ${ }^{20}$ This is certainly a valid approach, and one that saves time and resources (fig. 12). In our case, the realistic nature of our models demands that researchers may eventually have the ability to toggle on and off, or otherwise view marked or shaded elements that have been restored, so as to set them apart from the archaeologically attested elements. In addition, a source document should accompany all models, listing the original sources used, especially in cases where multiple and often competing reconstructions have been postulated.

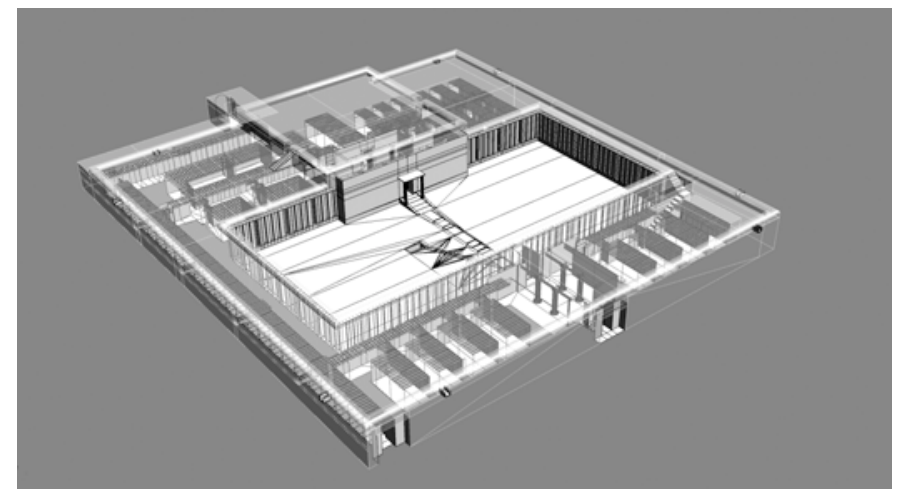

Fig. 12. Simplified rendering of the Menkaure Valley Temple, avoiding the challenges of realistic reconstruction based on fragmentary data.

Another challenge perhaps inherent to the nature of the material consists of determining exactly what type of structure from which era one is building. Should a particular mastaba reflect its condition in $2500 \mathrm{BC}$, upon the day of occupation by the tomb owner? Should it illustrate its condition upon discovery, millennia later, such as in 1912 of our era? Or should it display its condition now, in the present day? All of these choices are valid, and all have something to teach us. We have experimented with each of these phases; we have restored painted wall decoration to its original lustre in the Fourth Dynasty (fig. 9; G 7530-sub, Meresankh III), placed objects back in the tomb at the time of burial (fig. 6; G $7000 \mathrm{X}$, Queen Hetepheres); shown the condition upon discovery in 1906 (fig. 7; G 2100 shaft A, Sedit, described above), and presented the current condition of other monuments. In many cases, the nature of the surviving data will make the choice for us. We could never have restored the walls of Meresankh's chapel (fig. 9) if the colors had not survived so well down to the present day. And the burial shaft of Sedit (fig. 7), with each bone and wooden coffin fragment placed exactly in its original findspot, would likewise have been impossible without the photographs and drawings from the original HU-MFA Expedition. What has become clear is that, no matter which time period one shows, or how much reconstruction one attempts, it is paramount to indicate for the researcher what is attested, what is likely, and what is conjectural. Otherwise, one creates a construct for representing ancient Egyptian culture that may relate more to the prejudices of our own time than to the intentions of the original builders (fig. 13). ${ }^{21}$ Working out the best practices for visualization, and archaeological information management in general, remains a long-term goal of the Giza Project at Harvard.
[19] J. Wittur, Computer-Generated 3D-Visualisations in Archaeology. Between Added Value and Deception. Oxford: BAR, 2013. See also S. Moser, "Archaeological Representation: The Visual Conventions for Constructing Knowledge about the Past," in Archaeological Theory Today, Ian Hodder, Ed. Cambridge: Polity Press, 2001, pp. 262-283.

[20] See http://dai.aegaron.ucla.edu/index.php/welcome/about (accessed July 2013).
[21] L. Daston and P. Galison, Objectivity. New York: Zone Books, 2010; B.L. Molyneaux, The Cultural Life of Images. Visual Representation in Archaeology. London and New York: Routledge, 1997. 


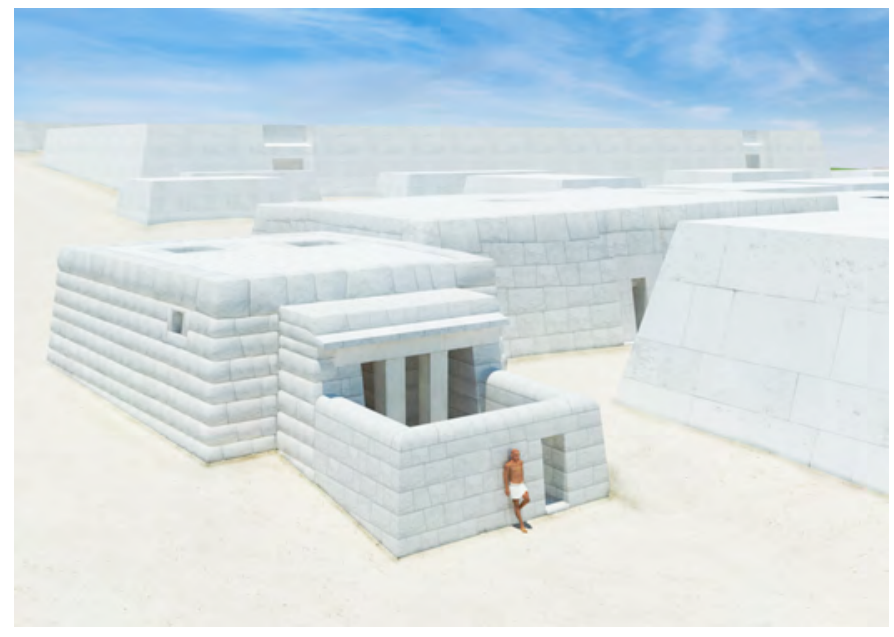

Fig. 13. 3D model reconstruction (with animated human character) of the tomb of Nensedjerkai (G 2100-II), looking northwest.

\section{Sustainability}

The ancient Egyptians committed much of their legacy to stone. In the early $20^{\text {th }}$ century, archaeologists at sites such as Giza began to convert that legacy from stone to glass plate photo negatives, paper notes, and drawings. In our era the medium is transferring once again, this time from paper and glass to electronic form and digital files. It is perhaps debatable which of these media is best suited to survive for posterity. A hieroglyphic inscription carved in stone has already stood the test of time, surviving, in the case at hand, for nearly 5,000 years. A glass plate negative by contrast can suffer from chemical deterioration, or cracking; and a digital file runs the risk of corruption, or failure to keep pace with software and hardware devices that will be able to access it. Initiatives such as the Giza Project endeavor to create a permanent archive using tools that, whether by unhappy chance or by conscious design (i.e. for commercial reasons) often become obsolete with alarming rapidity. In addition to off-site backup systems, and other redundancies, such initiatives require sustained funding to maintain and enhance them for future generations.

\section{CONCLUSIONS}

New technologies will continue to sort and display Giza records online in new and exciting ways. We can already pose research questions that previously could not be formulated, while the next frontier incorporates additional archaeological sciences. We look forward to online delivery of more precise monument georeferencing, augmented reality, satellite and low aerial photography, new remote sensing techniques, and enhanced, interactive 3D modeling of the tombs, temples, and settlements covering the site of the Giza Plateau. ${ }^{22}$

[22] I am indebted to the staff of the Giza Project at Harvard University: Egyptologists Nicholas Picardo, Rachel Aronin, and Jeremy Kisala, lead technical artist Rus Gant, and technical artist David Hopkins. I would also like to acknowledge the partnership and collaboration with the Museum of Fine Arts, Boston, particularly with my Egyptological colleagues there Rita E. Freed, Lawrence Berman, and Denise Doxey. For their support and technical assistance I thank our partners at

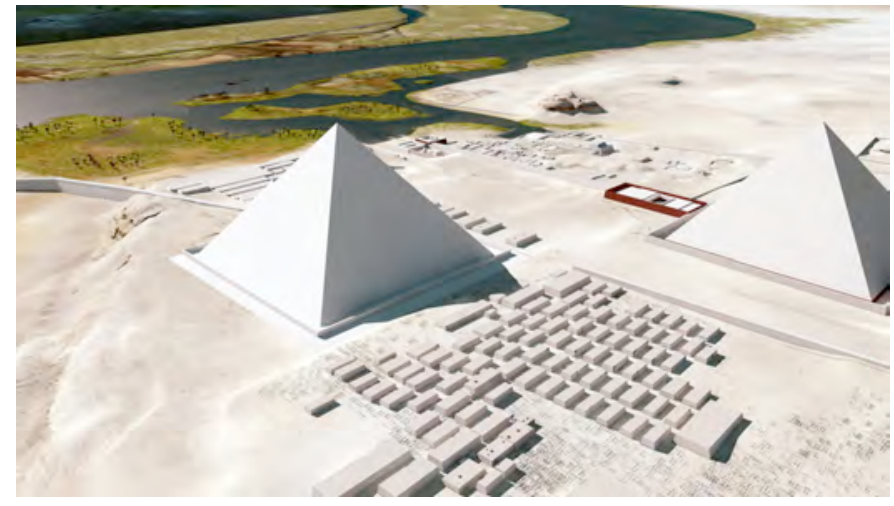

Fig. 14. Detail view of the 3D Giza Plateau model, looking southeast.
Dassault Systèmes: Mehdi Tayoubi, Karine Guilbert, and Isabelle Estebe. 